\title{
Die landsbelofte en grondbesit: Enkele perspektiewe op die boek Miga
}

J G Strydom

Universiteit van Suid-Afrita

\begin{abstract}
The land promise and the possession of land: A few perspectives on the book of Micah

In prophetic circles the whole crisis about justice centered around the issue of the land and its ownership, more specifically the unfavorable distribution of the land which took place. This means that the land promise, made to Abram, as well as the way in which the promised land was eventually taken possession of and distributed, formed the basis of the prophets critique against social injustice and their consequent call for justice. To illustrate this matter this article focuses on the book of Micah by analyzing the passages which deal with issues of social injustice.
\end{abstract}

\section{INLEIDEND}

Om volledig, binne die omvang van 'n enkele artikel, aan die Ou-Testamentiese siening van die land, die landsbelofte en die hele kwessie van grondbesit te probeer aandag gee, is 'n feitlik onmoontlike taak. Daar is eenvoudig te veel om te sê. Ek gaan myself dus beperk deur aan bepaalde aspekte van die landsbelofte aandag te gee, en dan op die boek Miga te konsentreer: Hoe moet die profeet Miga se siening oor aspekte soos die landsbelofte, die verdeling van die land en privaat grondbesit verstaan word? Daarmee saam wil ek ook kortliks aandag gee aan die vraag hoe sy uitsprake hieroor verband hou met die tema van geregtigheid.

\section{DIE PROFETE SE SIENING VAN GEREGTIGHEID}

\subsection{Geregtigheid en grondbesit}

Volgens Mays (1983:5) is die profetiese boeke dié gedeelte van die Bybel waar die tema van geregtigheid baie prominent funksioneer. 'n Verdere interessante opmerking van Mays (1983:10) in dié verband (wat veral vir die doel van hierdie artikel van belang is) is dat, binne die profetiese kringe, die hele krisis oor geregtigheid in werklikheid oor niks anders as juis die kwessie van die land en grondbesit gegaan het nie. Meer spesifiek het dit veral gedraai rondom die onreguerdige 
(her)verdeling van die land. Mays (1983:10) gaan selfs so ver as om te sê dat alles wat die profete oor geregtigheid te sê gehad het, selfs wanneer die landkwessie nie eksplisiet vermeld was nie, tog maar te doen gehad het met die land en grondbesit. Opmerklik is ook die siening van Donahue (1977:77) dat geregtigheid in die Ou Testament basies te doen het met die drieledige verhouding tussen God, andere (mense) en die land. Indien ek dit reg verstaan, is die implikasie van bogenoemde dat die land, en alles wat rondom die verdeling en eienaarskap daarvan ontwikkel het, tot 'n groot mate die basis gevorm het van die profete se kritiek teen sosiale onreg, en hulle gevolglike oproep tot reg en geregtigheid.

Om 'n standpunt soos hierdie te ontleed, sou 'n mens al die profetiese boeke volledig moes analiseer. Binne die besek van een artikel is dit egter onmoontlik. Daarom gaan ek, by wyse van 'n voorbeeld, my bloot op een boek, die boek Miga, toespits. Hopelik sal ek ook van die ander profetiese boeke by 'n later geleentheid aan die orde kan stel.

\section{Geregtigheid en grondbesit in die boek Miga}

In die lig van wat hierbo gesê is, is die vraag of dit wat Miga oor sosiale geregtigheid te sê gehad het vanuit die standpunt verklaar kan word dat dit (feitlik) alles te doen gehad het met hoe die land en die besit daarvan geïnterpreteer en georganiseer is? In Miga 2-5, wat kronologies die begin van sy profesieë vorm, is Miga in dispuut met die leiers van Jerusalem en kritiseer hy hulle vir die baie onreg wat gepleeg is. Inderdaad vind ons dat grondbesit die eerste saak is wat aan die orde kom:

Ellende wag vir julle wat rampe teen ander beplan, wat op die bed lê en dink aan kwaad om te doen,

wat dit vroeg in die môre gaan uitvoer omdat hulle die mag in die hande het.

Hulle begeer 'n stuk grond en vat dit, huise, en lê beslag daarop.

Hulle kul 'n man uit sy huis uit, 'n mens uit sy besitting uit.

(Miga 2:1-2)

Miga protesteer teen die wyse waarop die leiers die mense uitbuit deur hulle grond en eiendom van hulle af te vat. Die vraag mag onstaan waarom dit as uitbuiting gesien is en daarom as onaanvaarbaar. Was dit nie maar net goeie besigheid nie, en indien nie, waarom nie? Ten einde hierdie vraag te beantwoord, sal ons eers moet teruggaan in die geskiedenis om vas te stel wat die mense se geloof/wette/gebruike rondom land en eienaarskap was, en tweedens hoe dié wette en gebruike toegepas en/of misbruik is oor die jare. 


\section{DIE LANDSBELOFTE EN GRONDBESIT: 'N PERSPEKTIEF OP MIGA}

Bogenoemde is egter makliker gese as gedaan. Die probleem is waar om te begin. 'n Interessante siening in hierdie verband is die van Olson (1986:19) wat sê dat die landsbelofte wat aan Abram gemaak is (Gn 12) die primêre agtergrond verskaf vir 'n Bybelse perspektief op die land. Volgens hom kan vier elemente van die Bybelse perspektief op die land daarin gevind word, naamlik:

- die land as God se geskenk;

* die land en die familie;

- die land en die wêreld; en

- die land en die toekoms.

Ek is bewus daarvan dat hierdie maar een moontlike siening van die saak is, maar weer eens is dit ' $n$ feitlik onbegonne taak om 'n oorsig te bied oor al die passasies in die Ou Testament waar daar na die landsbelofte verwys word, of om 'n analise te maak van al die sienings van Ou Testamentici oor hoe die landsbelofte geïnterpreteer moet word. Ek het daarom besuit om Olson se siening te neem en te kyk watter lig dit op ons verstaan van die land en grondeienaarskap in daardie tyd werp.

Dit is egter eers nodig om kortliks aan 'n ander saak aandag te gee. Ek is bewus daarvan dat die nuwere Pentateugkritiek die siening handhaaf dat die landsbelofte as sodanig, met ander woorde die inhoud daarvan, 'n latere konstruksie is, moontlik selfs uit die tyd van die ballingskap. Vir die doel van hierdie artikel sou dit impliseer dat 'n mens nie die landsbelofte en die inhoud daarvan as agtergrond vir Miga se uitsprake kon gebruik nie, omdat dit 'n anakronistiese werkswyse sou wees. Ek meen egter dat daar ' $n$ onderskeid getref moet word tussen die 'opskrifstelling' van dié belofte en sy inhoud aan die een kant, en die 'teenwoordigheid' daarvan (in 'mondelinge' vorm) reeds lank voor daardie tyd. Wat ek dus wil sê is dat die (mondelinge) tradisies rondom die landsbelofte en die in-besit-neem van die land reeds in die tyd van Miga in omloop was en dat ons dit dus wel as agtergrond vir Miga se uitsprake kan gebruik.

\subsection{Die land as God se geskenk: Die land en die familie}

\subsubsection{Die land as God se geskenk}

Wat Olson se eerste aspek betref, naamlik die land as God se geskenk, is die meeste Ou Testamentici eenstemmig: Die implikasie van die belofte aan Abram was dat die land as 'n geskenk aan die patriarge en hulle nageslag gegee is. Brueggemann (1987:46) sê 'Israel's theory of the land...is that the land is assigned to the entire community as a trust from Yahweh...as "inheritance"...as a gift of God.' Kaiser (1981:303) sê in dié verband dat God alleen tussen die helftes van die offerdiere 
deurbeweeg het (Gn 15:7-21) en daarom het die volle verantwoordelikheid vir die uiteindelike skenking van die land op God alleen gerus, en nie (ook) op die toewyding van die patriarg nie. Die implikasie was dat die land steeds aan God behoort het: Hy het dit aan die patriarge belowe/gegee as hulle 'erfenis' (inheritance), maar dit was steeds slegs in teorie en nie in praktyk nie. Soos Kaiser (1981:306) dit stel: 'For over half a millenium it was only the land of their sojourning; they did not as yet possess it.'

Toe Abram afgetrek het na Egipte, het dit byna gelyk asof dit die einde van God se belofte aan hom was. Maar God het sy belofte aan Moses herbevestig toe hy aan hom die versekering gegee het dat die volk uit Egipte uitgelei sou word en weer na Kanaän sou terugkeer. Met die intog in Kanaän wat gevolg het, het die hele aard van die belofte verander. Waar die volk tot op daardie stadium nog nie die land 'besit' het nie, sou dit voortaan wel die geval wees.

Dit lyk vir my asof ons ten opsigte van hierdie 'in-besit-neem' van die land (die 'vervulling' van die belofte?) tussen 'n korporatiewe (makro) en 'n individuele (mikro) vlak sal moet onderskei. In soverre dit eersgenoemde aangaan, het dit geïmpliseer dat die land as 'n 'eenheid' deur die volk as geheel in besit geneem is. Weer eens is ek bewus van die feit dat daar meningsverskil bestaan oor presies hoe die land in besit geneem is. Is dit regtig as geheel in besit geneem? Hoe lank het die proses geduur? Hierdie vrae kan tot 'n lang bespreking op sigself lei. Wat egter vir my doel van belang is, is dat die land (tot een of ander mate) in besit geneem is.

Volgens Beegle (1977:24) het daar 'n nuwe element hiermee saam na vore gekom: Waar die belofte van die land tot op daardie stadium onvoorwaardelik was, het die verbond by Sinai toe gehoorsaamheid as 'n voorwaarde vir 'n lang verblyf in die beloofde land neergelê (Dt 6:2). Met ander woorde, alhoewel die land 'n geskenk was, kon ongehoorsaamheid daarna lei tot verlies van die land. 'n Mens sou kon sê dat die volk toe 'n tipe van korporatiewe verantwoordelikheid jeens God gehad het wat sou bepaal of hulle die land sou behou, of nie.

\subsubsection{Die land en die familie}

Op die individuele (mikro) vlak het die in-besit-neem van die land 'n verdere nuwe element na vore gebring, naamlik die verdeling daarvan. Moontlik is dit hier waar, saam met die eerste aspek, ook Olson se tweede aspek in spel kom, naamlik dat daar in die landsbelofte ingebou was dat daar ' $n$ baie hegte band tussen die land (grondbesit) en die familie wat dit besit het, sou wees. Die verskillende stamme het elkeen sy deel van die land ontvang en dit is toe verder tussen die families in die stam verdeel. Om die saak ietwat te oorvereenvoudig: Nie alleen het Israel as 'n geheel hulle 'geskenk' in besit geneem nie, maar ook kleiner groepe (families) het 
húlle deel van die geskenk in besit geneem. Die idee was dat elke familie voldoende grond moes hê om van te lewe. Die beginsel wat gegeld het, was gelykheid. Niemand was werklik in ' $n$ beter posisie as iemand anders nie, of is 'toegelaat' om sy posisie ten koste van iemand anders te verbeter nie. Die rede? Omdat die land gesien is as God se geskenk aan die volk as 'n geheel, maar ook aan elke invividu (familie) afsonderlik. Simbolies hiervan was die feit dat die land deur middel van die werp van die lot toegeken is.

Dit het ook beteken dat, alhoewel dit 'n geskenk was, elke familie 'n reg op hulle grond gehad het. Daarom is die grond ook van geslag tot geslag oorgedra (geërf) en het die familie die verantwoordelikheid gehad om om te sien na hulle grond. Dit is ook die rede waarom sekere reëls en wette, soos die Sabbatsjaar en die Jubeljaar, ingestel is om te verseker dat niemand sy 'geskenk' permanent kon verloor nie en dat sy stuk grond weer aan hom teruggegee sou word.

Hieruit blyk dat daar dus twee belangrike aspekte was in soverre dit die inbesit-neem van die land betref het. Eerstens was daar 'n bepaalde verantwoordelikheid jeens God: Hy het gehoorsaamheid verwag, anders kon hulle (korporatiewe) verblyf in die land kortgeknip word. Een element van hierdie verantwoordelikheid was ook dat die verdeling van die land deur God (die lot) gerespekteer moes word. Tweedens, voortvloeiende uit bogenoemde, was dat die mense ' $n$ bepaalde verantwoordelikheid teenoor mekaar gehad het om mekaar se reg tot grondbesit te respekteer, as synde elkeen se 'deel' van die geskenk van God.

Met die instelling van die monargie het teorie en praktyk egter begin bots en het alles verander. Waar die beginsel van gelykheid tot op daardie stadium gegeld het, het 'n nuwe verskynsel skielik na vore getree, naamlik verskillende sosiale klasse. Basies het dit om twee groepe gegaan: Die koning en sy amptenare aan die een kant en die boerderyfamilies aan die ander kant. Soos Olson (1986:23) dit stel: 'Many of the kings came to believe they were above the law of God and sought to concentrate ever more power and land in their own hands.' Die klassieke voorbeeld is waarskynlik dié van Agab en Nabot (1 Konings 21). Amptenare het, binne 'n nuwe ekonomiese situasie met sy besigheids- en grondtransaksies, hulle mag misbruik, en sodoende is die gelykheid wat daar tussen families bestaan het, vernietig (Herron 1986:77). Die 'nuwe motto' was om soveel grond en eiendom as moontlik te verkry, selfs ten koste van diegene wat nie ekonomies op hulle eie kon oorleef nie.

Wat dus gevolg het was dat telkens wanneer die grondeienaars gespook het om te oorleef, die landheer, wat meesal uit die staatsamptenary afkomstig was, tot die 'redding' toegetree het. Lang (1982:50-51) noem drie tipes landbewoner-landheerverhoudings wat in die Ou Nabye Ooste bestaan het: 
- 'Patronage': Die landheer het sy 'kliënt' beskerm en het verantwoordelikheid aanvaar vir hom en sy familie se voortbestaan, terwyl die landbewoner 'n deel van sy oes aan die landheer gegee het.

- Vennootskap: In so 'n geval was daar byvoorbeeld 'n 50:50 verdeling van die oes wat daartoe gelei het dat beide vennote gebaat het by goeie jare.

- Uitbuiting: Die landheer was alleen op wins ingestel, en het geen lojaliteit teenoor die landbewoner gehad nie.

Volgens Lang (1982:51-52), in soverre dit Bybelse Israel aangaan, was daar twee sisteme waarvolgens 'n landbewoner krediet kon verkry:

- Hy kon na 'n familielid gaan om geld te leen of hy kon 'n stuk grond aan hom verkoop in welke geval die familielid die rol van 'n 'patron' vervul het (soos byvoorbeeld Jeremia).

- In die tweede geval was dit 'n suiwer besigheidstransaksie waarin die landheer geen verpligting teenoor die landbewoner gehad het nie en wat meeste van die tyd tot uitbuiting gelei het.

\subsection{Miga se uitsprake teen hierdie agtergrond}

Uit die profetiese boeke is dit duidelik dat dit veral laasgenoemde was wat meer dikwels voorgekom het. Dit het so sleg gegaan dat selfs nie die talle wette wat die armes moes beskerm die situasie meer kon beredder nie. Die gevolg was dat die profete hierdie mense se saak moes opneem ten einde te verhoed dat hulle dit verloor waarop hulle 'n reg gehad het en wat noodsaaklik vir hulle voortbestaan was, naamlik 'n stukkie grond om op te leef en van te leef. Daarom is ek dan ook van mening dat dit juis teen hierdie agtergrond is dat ons Miga se woorde in 2:1-2 moet verstaan:

Ellende wag vir julle wat rampe teen ander beplan, wat op die bed le en dink aan kwaad om te doen,

wat dit vroeg in die môre gaan uitvoer omdat hulle die mag in die hande het.

Hulle begeer 'n stuk grond en vat dit, huise, en lê beslag daarop.

Hulle kul 'n man uit sy huis uit, 'n mens uit sy besitting uit.

(Miga 2:1-2) 
Hierdie woorde van Miga het te doen met wat ek hierbo die individuele vlak genoem het, met ander woorde dit gaan in feite oor die probleem van individuele grondbesit en nie oor die besit van die land as geheel deur die volk as geheel nie. Sonder twyfel het Miga die nuwe ekonomiese situasie aangeval waarbinne die staatsampenare (die ryk landhere) die arm plaasboere uitgebuit het. Hulle het hulle grond en eiendom afgevat sonder enige intensie om dit terug te gee ('hulle begeer 'n stuk grond en vat dit; huise, en lê beslag daarop' - Miga 2:2a). As gevolg hiervan is die arm boere ook hulle menswaardigheid ontneem ('hulle kul 'n man uit sy huis uit, 'n mens uit sy besitting uit' - Miga 2:2b); sonder grond van hulle eie het hierdie mense geen plek in die samelewing gehad nie en is hulle as't ware tot die vlak van slawe verneder.

Miga 2:8-9 skets 'n soortgelyke prentjie:

My volk het in die afgelope tyd ' $n$ vyand geword

en in opstand gekom;

julle stroop die mooi klere af van dié wat houtgerus

by julle verbystap soos soldate van die slagveld af.

Julle jaag die vrouens van my volk

uit hulle gerieflike huise uit,

julle vat die blywende gerief wat Ek hulle gegee het,

van hulle kinders af weg.

(Miga 2:8-9)

In 'n neutedop gaan dit om weduwees wat nie langer op hulle grond kan oorleef nie, en wat dan deur die landhere uitgebuit word totdat hulle uiteindelik geen plek meer het om te bly nie. Hulle kinders word as slawe geneem en so hulle menswaardigheid ontneem.

Miga se kritiek het dus te doen met die twee 'verantwoordelikhede' ten opsigte van die besit van die land waarna ek vroeër verwys het. Eerstens het die leiers nie hulle verantwoordelikheid teenoor God nagekom nie. Met die belofte van die land was God se bedoeling dat dit 'n geskenk en 'n erfenis (inheritance) aan die hele volk moes wees (dit hou nóú verband met Olson se eerste aspek, naamlik die land as geskenk). Die leiers het dus die verantwoordelikheid teenoor God gehad om toe te sien dat die wyse waarop die land verdeel is, gerespekteer en in stand gehou word. Tweedens het die leiers ook hulle menslike verantwoordelikheid teenoor hulle volksgenote verontagsaam, naamlik om hulle belange te beskerm en respek te toon vir die noue band wat daar tussen 'n bepaalde familie en hulle grond bestaan het (Olson se tweede aspek). 
Ook die res van wat Miga oor geregtigheid te sê het, moet in hierdie lig en teen hierdie agtergrond gesien word. Volgens Miga 3:2 is die leiers haters van wat goed is en liefhebbers van wat verkeerd is. Die goeie, naamlik om die mense van die volk te beskerm, het hulle nie gedoen nie, terwyl die verkeerde, naamlik om die mense uit te buit, presies is wat hulle wel gedoen het: hulle eet die volk op asof hulle vleis is (Mi 3:3); hulle praat slegs van vrede solank as wat hulle kos kry, en as iemand hulle nie bly instop nie, verklaar hulle oorlog teen hom (Mi 3:5); die leiers lewer uitspraak vir omkoopgeld, die priesters gee onderrig teen salaris en die profete maak voorspellings teen betaling (Mi 3:11). Met ander woorde, selfs wanneer diegene wat uitgebuit is hulle op die regstelsel beroep het, was dit geld en persoonlike belang wat die uitspraak bepaal het.

Die oordeel wat Miga aankondig, is verdoemend:

Daarom, so sê die Here:

Ek beplan 'n ramp teen hierdie mense, hulle sal dit nie kan ontwyk nie,

Hulle sal nie meer regop kan loop nie, want dit sal'n tyd van swaarkry wees.

Daardie dag sal hulle 'n spotlied oor jou maak, hulle sal 'n klaaglied sing en sê:

Ons is geheel en al vernietig, my volk se besittings is opgedeel,

dit is van ons afgevat, ons land is onder verraaiers verdeel.

Daarom sal jy nie meer iemand in die gemeente van die Here hê om jou land te verdeel nie.

(Miga 2:3-5)

Maak klaar, gee pad!

Dit is nie julle blyplek nie, want dit is onrein en verwoes, onherstelbaar verwoes!

(Miga 2:10)

Wanneer hulle (die leiers) tot die Here roep sal Hy hulle nie antwoord nie.

Dan sal Hy Hom nie aan hulle openbaar nie, want hulle het baie verkeerd gehandel ....

Die son sal ondergaan vir hierdie profete, die dag sal pikdonker word oor hulle.

(Miga 3:4, 6) 
Hierdie oordeel funksioneer steeds op wat ek die individuele vlak genoem het. As gevolg van hulle gierigheid word die leiers (landhere) daarop gewys dat hulle nie alleen die grond wat hulle onwettig verkry het, sal verloor nie, maar ook hulle eie grond. Hulle sal vernietig word, hulle grond sal afgevat word en dit sal gegee word aan diegene aan wie dit oorspronklik behoort het en wat besig was om rond te trek sonder vaste blyplek. In Miga 2:4 word hulle juis beskryf as 'die rondtrekkendes' hier stem ek saam met Van der Woude (1976:72) dat die woord wat gewoonlik (ook in die $\mathrm{NAB}$ ) met 'verraaiers' vertaal word, eerder met 'rondtrekkendes' vertaal moet word. Miga 2:5 stel dit ook duidelik dat hulle nooit weer grond van bulle eie sal besit nie, aangesien daar niemand sal wees om grond aan hulle toe te ken deur die werping van die lot nie (die wyse waarop ook hulle aanvanklik hulle grond gekry het). Hulle sal hulle blyplek moet verlaat (Mi 2:10) en selfs wanneer hulle na die Here roep om hulp, sal Hy hulle nie antwoord nie (Mi 3:4). Ook die valse profete wat saam met die leiers gekonkel het, sal hulle profetiese gawe verloor (Mi 3:5).

Om saam te vat ten opsigte van hierdie vlak (met die hulp van Olson se eerste twee aspekte): Die verskillende families het elkeen hulle stuk grond ontvang as deel van God se geskenk. Tussen die familie en hulle grond was daar 'n baie hegte band en God het van almal verwag om dit te respekteer. Diegene wat dit nie gedoen het nie, was dus gedoem om hulle deel van die geskenk (grond) te verloor.

\section{Die land en die wêreld: Die land en sy toekoms}

\subsubsection{Die land en die wêreld}

Volgens Olson (1986:24) het God die land nie alleen ter wille van individuele families geskenk nie, maar ook (en uiteindelik) ter wille van ander families regoor die wêreld. Om die rede is daar dan ook aan Abram gesê dat in hom al die volke van die aarde geseën sou wees (Gn 12:3). God skenk dus die land aan Abram en sy nageslag om vir die hele wêreld tot seën te wees.

\subsubsection{Die land en sy toekoms}

Olson (1986:25) meld verder dat God die land geskenk het, egter nie soseer aan Abram as persoon nie, maar aan sy kinders en al die geslagte wat daarna sou kom. Daar was dus ' $n$ toekomsdimensie in die belofte ingebou wat onder andere daarin na vore kom dat Abram self nooit werklik die land besit het nie. Die hoop en verwagting het egter bly leef dat die belofte iewers in die toekoms sou realiseer, met ander woorde daar was maar altyd 'n element van onsekerheid oor wat die toekoms sou inhou. 


\subsection{Miga se uitsprake teen hierdie agtergrond}

As ons nou terugkeer na wat Miga gesê het, dan lewer hierdie agtergrond 'n besondere perspektief. Waar Miga tot op hierdie stadium in sy profesieë slegs op die individuele vlak gekonsentreer het, het die korporatiewe vlak toe ook onder die loep gekom. Dit was nie net privaat eienaarskap wat meer op die spel was nie, maar ook die volk se korporatiewe besit van die land. Met ander woorde, volgens Miga het dit wat op individuele vlak gebeur het, ook konsekwensies vir die korporatiewe vlak gehad.

Na my mening is hierdie presies die plek waar Olson se derde en vierde aspekte ter sprake kom, naamlik die land en die wèreld en die land en die toekoms. Waar die eerste twee aspekte hoofsaaklik met die individuele vlak te doen gehad het, het hierdie twee meer met die korporatiewe vlak te doen.

Daar is duidelik twee elemente betrokke by dit wat Miga op die korporatiewe vlak te sê het. Eerstens is daar wat ons 'n negatiewe kant kan noem, aangesien dit gaan oor oordeel en katastrofe.

Daarom is dit julle skuld dat Sion soos 'n stuk land geploeg sal word,

dat Jerusalem 'n puinhoop sal word, dat die tempelberg ' $n$ hoogte vol bossies sal word.

(Miga 3:12)

Krul van die pyn, Sion, kry geboortepyne soos 'n vrou in kraam!

Jy moet nou die stad verlaat,

jy moet in die oop veld gaan woon

en na Babel toe gaan....

(Miga 4:10)

Jy is nou vasgevang, rowerstad!

Ons word beleër!

Die vyand sal die koning van Israel

met 'n kierie op die kakebeen slaan.

(Miga 4:14)

As gevolg van die baie onreg wat op die individuele vlak gepleeg is, was die toekoms van die land, op die korporatiewe vlak, nou ook gedoem, aangesien dit deur die wêreld (die vyand) ingeneem sou word. Die punt waarom dit gaan, is dat die onreg en uitbuiting nie alleen op 'menslike' vlak plaasgevind het nie (mens teen mens wat mekaar se grond vat), maar dit was ook 'n verbreking van die verantwoordelikheid wat die mense teenoor God gehad het: Die voorwaarde met die in-besit-neem van 
die land, en afles wat daarmeee gepaard gegaan het, was immers dat gehoorsaamheid aan God sou bepaal of die volk die land sou behou, of nie. Daarom kondig Miga aan dat nie alleen net die leiers, as gevolg van al die onreg wat gepleeg is, hulle eie privaat grond sou verloor nie, maar dat ook die ganse volk die beloofde land as sodanig sou verloor en dat hulle boonop in ballingskap sou gaan. Die betrokkenheid van die wêreld sou daarom as 'n katastrofe ervaar word, omdat sit sou impliseer dat die toekoms van die land in die hande van die 'wêreld' sou wees en nie meer die volk self nie.

Daar is egter 'n ander kant van die saak ook: Miga sê dat, alhoewel hierdie ballingskap onvermydelik is, daar tog hoop vir die toekoms is.

(...jy moet...na Babel toe gaan.)

Daar sal jy gered word,

daar sal die Here jou verlos

uit die mag van jou vyande.

(Miga 4:10)

(Die vyand sal die koning van Israel

met 'n kierie op die kakebeen slaan.)

...maar uit jou sal daar iemand kom wat aan My behoort

en hy sal in Israel regeer.

...Dan sal dié uit sy familie wat die ramp oorleef het, terugkom na die Israeliete toe.

...Hulle sal woon tot in die uithoeke van die aarde want hulle leier sal sterk wees.

(Miga 4:14-5:3)

Dié van Jakob wat oorbly

sal tussen baie volke wees,

hulle sal daar wees soos dou wat van die Here af kom, soos stortreëns op groen gras

wat nie vir 'n mens wag nie, nie na mense kyk nie.

(Miga 5:6)

As die volk bereid was om hulle weer te bekeer en gehoorsaam te word, dan het die moontlikheid bestaan dat hulle weer na die beloofde land kon terugkeer, Daarom was daar ook hoop vir die toekoms van die land. Die volk sou toegelaat word om weer die land in besit te neem en sodoende sou die belofte van die land 'her'-vervul word soos dit aan Abram belowe is: 'Die hele land wat jy sien, gee Ek vir altyd aan jou en jou nageslag' (Gn 13:15). Watter rol sou die wêreld dan speel? Die nuwe 
regeerder van Israel sou regeer tot aan die eindes van die aarde (Mi 5:3), met ander woorde die wêreld sou deel word van die beloofde land en sy toekoms. Wat meer is, Israel sou 'n bron van seën vir die ander nasies wees, net soos dou en reën 'n seën vir die grond was (Mi 5:6). Sodoende sou vervul word wat God ook aan Abram gesê het: 'In jou sal al die volke van die aarde geseën wees' (Gn 12:3).

Om saam te vat in soverre dit hierdie korporatiewe vlak aangaan (met die hulp van Olson se laaste twee aspekte): As gevolg van die volk se ongehoorsaamheid het die onmiddellike toekoms duister gelyk aangesien die land deur die 'wêreld' afgevat sou word. Daar was egter hoop; die toekoms van die land sou herstel word en die wêreld sou deel in die seëninge van die land.

\section{ENKEIE GEVOLGTREKKINGS}

In die lig van bogenoemde kan nou tot 'n aantal gevolgtrekkings geraak word ten opsigte van die oogmerke wat ek aan die begin gestel het.

In soverre dit die boek Miga aangaan, het dit wat Miga oor sosiale geregtigheid te sê gehad het, grootliks te doen gehad met die hele kwessie van land- en grondbesit. Vanuit die staanspoor is sy kritiek gerig teen wanpraktyke rondom grondbesit en die wyse waarop mense uit hulle grond verkul is, selfs tot so 'n mate dat hulle menswaardigheid aangetas is. Waneer hy ander aspekte kritiseer, byvoorbeeld juridiese en godsdienstige wanpraktyke, dan hou dit ook duidelik verband met die hele grondkwessie. Myns insiens open dit 'n bepaalde perspektief ten opsigte van die profete se kritiek op sosiale onreg wat gerus ook ten opsigte van ander bepaalde profete ondersoek kan word.

Wat spesifiek die inhoud van Miga se kritiek op hierdie wanpraktyk betref, meen ek verder dat bogenoemde analise heelwat daartoe bydra om dit wat Miga gesê het, in breër perspektief te plaas. Dit is ook duidelik dat veral die vier aspekte rondom die landsbelofte (OIson se teorie) daartoe bydra om Miga se uitsprake in konteks te plaas. Miga kritiseer nie maar net omdat die uitbuiting as sodanig sosiaal onaanvaarbaar was nie, maar veral omdat die landsbelofte en die inhoud daarvan deur die wanpraktyke in gedrang gebring is. Dit het ook nie maar net gegaan om mense wat mekaar uitbuit met onwettige transaksies nie, maar om 'n 'bedeling', wat deur God self daargestel is, wat in die proses afgebreek is. Omdat die land primer God se geskenk aan die volk as geheel, en aan elke familie individueel was, moes die verdeling daarvan gerespekteer en gehandhaaf word.

Dit wat Miga uiteindelik oor die verlies en moonlike herstel van die land te sê gehad het, maak ook baie meer sin in die lig van die besondere rol wat die 'wêreld' en die 'toekoms' daarin gespeel het. Die volk moes op die harde manier leer dat die land ook vir ander volke tot seën moes wees (Mi 5:6) ten einde die belofte aan 
Abram (Gn 12:3) in volle vervulling te laat gaan. Ironies genoeg het die toekoms van die land dus eintlik tot aan die 'einde' in die weegskaal bly hang, net soos Abram ook maar in ' $n$ groot mate in die verwagting moes leef dat die belofte vervul sou word.

\section{Literatuurverwysings}

Allen, L C 1976. The books of Joel, Obadiah, Jonah and Micha. Grand Rapids: Eerdmans. (NIC.)

Beegle, D 1977. The promise and the promised land: Israel the people and Israel the territory. Sojoumers 6, 24-27.

Brueggemann, W 1987. Land: fertility and justice, in Evans, B \& Cusack, G (eds), Theology of the land, 41-68. Minnesota: Collegeville.

Donahue, J R 1977. Biblical perspectives on justice, in Haughey, J C (ed), The faith that does justice, 68-112. New York: Paulist.

Hillers, D R 1984. Micah: A commentary on the book of the prophet Micah. Philadelphia: Fortress. (Hermeneia.)

Herron, R B 1986. The land, the law and the poor. Word and world: Theology for Christian Ministry 6/1, 76-84.

Kaiser, W C 1981. The promised land: A biblical-historical view. Bibliotheca Sacra 138/552, 302-312.

Lang, B 1982. The social organization of peasant poverty in biblical Israel. JSOT 24, 47-63.

Mays, J L 1976. Micah: A commentary. London: SCM. (OTL.)

— 1983. Justice: Perspectives from the prophetic tradition. Interp. 37/, 5-17.

Olson, D T 1986. Biblical perspectives on the land. Word and world: Theology for Christian Ministry 6/1, 18-27.

Renaud, B 1977. La formation du livre de Micée: Tradition et actualisation. Paris: Gabalda. (EtB.)

Rudolph, W 1975. Micha-Nohum - Habakuk - Zephanja: Mit einer Zeittafel von Alfred Jepsen. Gütersloh: Gerd Mohn. (KAT 13,3.)

Strydom, J G 1988. Micah, Anti-Micah and Deutero-Micah: A critical discussion with A S van der Woude. Unpublished DTh-thesis, University of South Africa, Pretoria.

Van der Woude, A S 1976. Micha. Nijkerk: Callenbach (POT.)

Wolff, H W 1982. Dodekapropheton 4: Micha. Neukirchen-Vluyn: Neukirchener. (BKAT.) 